\title{
Patterns of productivity during eutrophication: a mesocosm experiment
}

\author{
Candace A. Oviatt, Aimee A. Keller, Peter A. Sampou, Lynn L. Beatty \\ Marine Ecosystems Research Laboratory, Graduate School of Oceanography, University of Rhode Island, Narragansett, \\ Rhode Island 02882-1197, USA
}

\begin{abstract}
In a 28 mo mesocosm experiment, levels and patterns of productivity and respiration were observed for a range of nutrient additions selected to provide a gradation from conditions in lower Narragansett Bay, Rhode Island, USA, to maximum impact for an urban estuary receiving present day levels of sewage effluents. For a 32 -fold increase in nutrients, system apparent production increased by only a factor of 3.5. Seasonal patterns of autotrophy during the winter-spring diatom bloom and heterotrophy during summer and early fall occurred at all treatment levels. With the exception of the $8 \times$ treatment, all treatments above $2 \times$ had a greater respiratory demand in the water column than the benthos. The highest treatment mesocosm $(32 \times)$ went briefly anoxic during the second summer of the experiment during a period when little productivity was occurring in the water column.
\end{abstract}

\section{INTRODUCTION}

The winter-spring diatom bloom dominates the seasonal cycle of productivity in many temperate estuaries and coastal waters (Margalef 1958, McLaughlin et al. 1982, Smetacek et al. 1984). Contrary to growth patterns dependent on temperature, maximum diatom biomass often occurs during the coldest portion of the year and has been one of the most reliable annual events in the ecology of Narragansett Bay (Pratt 1965, Smayda 1976). This winter bloom, which occurred every year of a 14 yr study, usually begins in December but has started as early as November (1968) and as late as February (1965). While maximum abundance usually occurs in January, it has been as late as March (1964, 1969) and April (1966) (Smayda 1976). This seasonal signature in phytoplankton usually produces a biomass in excess of $20 \mu \mathrm{g}$ chlorophyll $\mathrm{al}^{-1}$ in lower Narragansett Bay. The magnitude of this bloom may be determined by nutrient limitation (Pratt 1965, Smayda 1973) and low temperature control on pelagic and benthic grazing rates (Martin 1965, Deason 1980, Durbin \& Durbin 1981, Deason \& Smayda 1982).

While attention in the 1950's and 1960's focused on these major diatom blooms, interest shifted to summertime metabolic patterns in the 1970's. During summer, the less than $10 \mu \mathrm{m}$ size fraction of phytoplankton can account for greater than $50 \%$ of production and respi- ration (Durbin et al. 1975, Furnas et al. 1982, Williams 1984). Although small diatoms can dominate summer production (Furnas 1982), flagellates usually dominate (Durbin et al. 1975). Summer primary production, which may equal or exceed that of the winter-spring bloom, is restrained by the availability of nutrients and grazing activities of herbivores/omnivores (Williams 1984). Summer respiration is regulated by temperature and available organic matter.

Annual production estimates of coastal waters do not have a wide range of values despite the wide range of nutrient enrichment encountered (Nixon 1984). In the northeast United States, sound and shelf net production values range from 100 to $380 \mathrm{~g} \mathrm{C} \mathrm{m}^{-2} \mathrm{yr}^{-1}$ (Platt \& Subba Rao 1973), and most estuaries range from 100 to 500 (Nixon \& Pilson 1983). A recent 7 yr study in mid Chesapeake Bay indicated a range in productivity of 357 to $783 \mathrm{~g} \mathrm{C} \mathrm{m}^{-2} \mathrm{yr}^{-1}$ with annual variability associated with river flow (Boynton et al. 1982). One long term experiment in sewage ponds presented control values of 621 and treatment values of $929 \mathrm{~g} \mathrm{C} \mathrm{m}^{-2} \mathrm{yr}^{-1}$ (Day 1983). A factor of 5 seems to be about the limit for estuaries, although higher and lower productivity values in estuaries apparently occur under special circumstances.

The purpose of this paper is to examine the impact of nutrients added in sewage-derived ratios on annual magnitudes and seasonal patterns of metabolism in the 
northeast estuarine environment. The intent is to define system periods of autotrophy and heterotrophy, to correlate types of phytoplankton with these periods, and to examine partitioning of metabolism between the water column and benthos. The range of nutrient additions to mesocosms was selected to provide a gradation from conditions in lower Narragansett Bay to maximum impact expected for an urban estuary receiving present day levels of sewage effluents. A simplification in the experiment was to add the nutrients in reagent grade, dissolved, inorganic form and to observe effects without the complication of all the other pollutants (metals and organics) present in sewage effluents.

\section{METHODS}

The experiment. From June 1981 through September 1983, a nutrient addition experiment was conducted in 9 mesocosms (Nixon et al. 1984). Reagent grade inorganic nutrients $\left(\mathrm{NH}_{4} \mathrm{Cl}, \mathrm{KH}_{2} \mathrm{PO}_{4}, \mathrm{Na}_{2} \mathrm{SiO}_{3}\right.$ were added in molar ratios found in Providence River sewage effluents: $12.80 \quad N: 1.00 \quad P: 0.91$ Si. Six mesocosms received inorganic nutrients daily during the morning mixing period in a logarithmic series representing the average sewage effluent-nutrient (dissolved inorganic) input to Narragansett Bay on an areal basis $(1 \times)$. Thus the series included $1 \times\left(2.88 \mathrm{mM} \mathrm{N} \mathrm{m}^{2} \mathrm{~d}^{-1}, 0.23 \mathrm{mM}\right.$ $\left.P \mathrm{~m}^{2} \mathrm{~d}^{-1}, 0.19 \mathrm{mM} \mathrm{Si} \mathrm{m} \mathrm{m}^{-2} \mathrm{~d}^{-1}\right), 2 \times, 4 \times, 8 \times, 16 \times$, and $32 \times ; 3$ additional mesocosms acted as controls for the experiment.

Mesocosms. The 3 control mesocosms were designed to have regimes of temperature, mixing, turnover, and light similar to a relatively clean northeast estuary with no major sewage inputs (Fig. 1) (Pilson et al. 1979, Nixon et al. 1980, Oviatt et al. 1981). The 6 treatment mesocosms had the same regimes but received the nutrient treatments described above. The temperature of the water followed within $2 \mathrm{C}^{\circ}$ that of the bay at the Graduate School of Oceanography dock in the west passage of Narragansett Bay. Plungers mixed the mesocosms on a schedule of $2 \mathrm{~h}$ on, $4 \mathrm{~h}$ off to mimic tidal currents and to suspend bottom sediments to the same concentration as in the bay (ca $3 \mathrm{mg} \mathrm{I}^{-1}$ ). During each period of mixing, $120 \mathrm{l}$ (or $480 \mathrm{l} 24 \mathrm{~h}^{-1}$ ) of bay water flowed into the mesocosms over a $12 \mathrm{~min}$ period to give a water column turnover time of $27 \mathrm{~d}$ (Pilson 1985). The $5 \mathrm{~m}$ deep water column prevented most sunlight (usually less than $1 \%$ ) from reaching the bottom thus maintaining sediments in a heterotrophic condition. The walls of the mesocosms were brushed twice a week in summer and weekly during the rest of the year to reduce fouling.

Total system oxygen metabolism. Daily production and night respiration were estimated weekly from

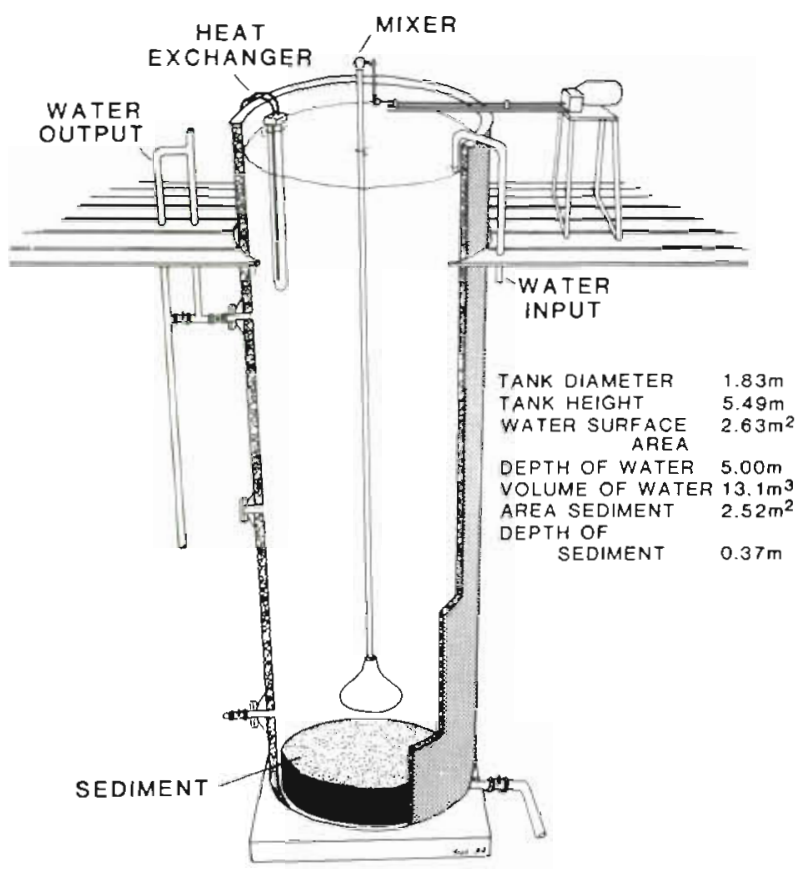

Fig. 1. Cross section of a MERL mesocosm showing input and output pipes, mixer, sediment container and heat exchanger. The tanks are constructed of fiberglass reinforced resin and have white interior walls to maximize the reflection of sunlight. Seawater is fed in a pulsed flow of $10 \mathrm{l} \mathrm{min}^{-1}$ for a 12 min period every $6 \mathrm{~h}$. Temperature control is accomplished with glass heat exchangers which can both heat and cool Mixing is accomplished with a plunger, $50 \mathrm{~cm}$ diameter. which moves in a vertical excursion of $60 \mathrm{~cm}$ at a rate of 5 cycles min $^{-1}$ for one $2 \mathrm{~h}$ period each $6 \mathrm{~h}$

consecutive dawn-dusk-dawn oxygen measurements (Odum \& Hoskin 1958). Oxygen concentrations were determined from Winkler titration (modified by Carritt \& Carpenter 1966) with a precision of $\pm 0.05 \mathrm{mg} \mathrm{O}_{2} \mathrm{l}^{-1}$. The bottles ( $60 \mathrm{ml} \mathrm{B}$. O. D.) were filled from the bottom with a siphon and allowed to overflow to eliminate air bubbles. Samples were fixed immediately and titrated within $24 \mathrm{~h}$. The oxygen concentration ( $\mathrm{mg} \mathrm{l}^{-1}$ ) at dawn was subtracted from the dusk oxygen concentration to calculate daytime production. This value in $\mathrm{mg} \mathrm{l}^{-1}$ was multiplied by the depth of the tank $(5 \mathrm{~m})$ to convert to $\mathrm{g} \mathrm{m}^{-2}$, then divided by the number of hours between dawn and dusk sampling times. The resulting value $\left(\mathrm{O}_{2} \mathrm{~g} \mathrm{~m}^{-2} \mathrm{~h}^{-1}\right)$ was corrected for oxygen diffusion from or to the atmosphere. Diffusion flux was calculated from an empirical linear regression derived from measurements in MERL tanks (Roques 1985). A dome floating at the tank surface was flushed with $\mathrm{N}_{2}$ and the increase in $\mathrm{O}_{2}$ was monitored:

$$
\begin{array}{cc}
\text { diffusion flux }=f(0.1) & \left(\operatorname{tank} \mathrm{O}_{2}-\mathrm{O}_{2}\right. \text { saturation) } \\
\mathrm{g} \mathrm{O}_{2} \mathrm{~m}^{-2} \mathrm{~h}^{-1} & \mathrm{mg} \mathrm{l}^{-1} \mathrm{mg} \mathrm{l}^{-1}
\end{array}
$$

where $\mathrm{f}=$ a temperature dependent gas exchange 
coefficient determined empirically. Diffusion flux (+ or -) was added to uncorrected production values and multiplied by the number of daylight hours (sunrise to sunset) to estimate daily oxygen production. Nighttime respiration was calculated in a similar manner using dusk-dawn samples.

Trapezoidal integration was used to calculate mesocosm production and respiration per season and per year. In 3 control tanks over 2 annual cycles the coefficient of variation (c.v.) in production was from 5 to $6 \%$, whereas for night respiration it was from 4 to $12 \%$.

Dawn-dusk-dawn $p H$. Water samples were siphoned from the tanks, taking care not to trap air in the bottles, and transferred to a temperature control bath set for in situ tank temperature. The $\mathrm{pH}$ meter was standardized monthly with fresh buffers of $\mathrm{pH} 9, \mathrm{pH} 7$ and $\mathrm{pH} 4$. It was rechecked using $\mathrm{pH} 7$ buffer solution prior to each dawn or dusk measurement and samples were read within $1 \mathrm{~h}$. Our precision was $\pm 0.02 \mathrm{pH}$ units.

Benthic respiration. Benthic oxygen uptake was measured monthly during summer months and seasonally during the rest of the year. A plexiglass chamber lowered into the mesocosms covered the entire benthic surface to make these measurements. A control bottle to correct for water column metabolism was incubated during the same period as the chamber incubation. Replicate initial and final samples provided oxygen determinations. Winkler titrations modified by Carritt \& Carpenter (1966) were carried out within $24 \mathrm{~h}$ with a precision of $\pm 0.05 \mathrm{mg} \mathrm{O}_{2} \mathrm{l}^{-1}$. Periods of benthic incubation were modified throughout the year to reduce undue impacts on oxygen concentration. Trapezoidal integration was used to calculate benthic metabolism per season and per year.

Chlorophyll and dissolved inorganic nutrients. Biomass of phytoplankton was sampled weekly in all mesocosms during the mixing cycle by chlorophyll a analysis (Yentsch \& Menzel 1963, Lorenzen 1966). Variability inherent in the analysis has been reduced by the dual standard method (Donaghay unpubl.). Replicate $10 \mathrm{ml}$ aliquots of sample water were filtered onto a $25 \mathrm{~mm}$ glass fiber filter and stored until analysis under dark, dry, frozen conditions. Extractions for chlorophyll were made with $90 \%$ acetone and read on a Turner Model III fluorometer.

Dissolved inorganic nutrients $\left(\mathrm{NH}_{3}, \mathrm{NO}_{2}, \mathrm{NO}_{3}\right.$ and $\mathrm{SiO}_{4}$ ) were sampled weekly in all mesocosms during the mixing cycle and analysed on a Technicon Autoanalyser (Beach 1983). Sea water samples were filtered through a $0.6 \mu \mathrm{m}$ Nuclepore filter and analysed immediately or frozen in an upright position. Primary and secondary standards (in sea water) were used to calculate concentrations. Standard deviations were $\pm 0.03 \mu \mathrm{M}$ for $\mathrm{NH}_{3}, \pm 0.01 \mu \mathrm{M}$ for $\mathrm{NO}_{2}$ and $\mathrm{NO}_{3}$ and $\pm 0.05 \mu \mathrm{M}$ for $\mathrm{SiO}_{4}$

\section{RESULTS}

\section{Time series: oxygen, $\mathrm{pH}$, and temperature}

Time series data on oxygen concentration indicate alternating periods of autotrophy and heterotrophy (oxygen above and below saturation, respectively) in all treatments (Fig. 2). In control treatments, periods of autotrophy occurred most strongly during winterspring bloom periods whereas heterotrophy occurred from mid summer to fall. This pattern generally occurred up the nutrient gradient with amplitude and rate of change increasing with increasing nutrient enrichment. For example, during the summer of 1982, a short
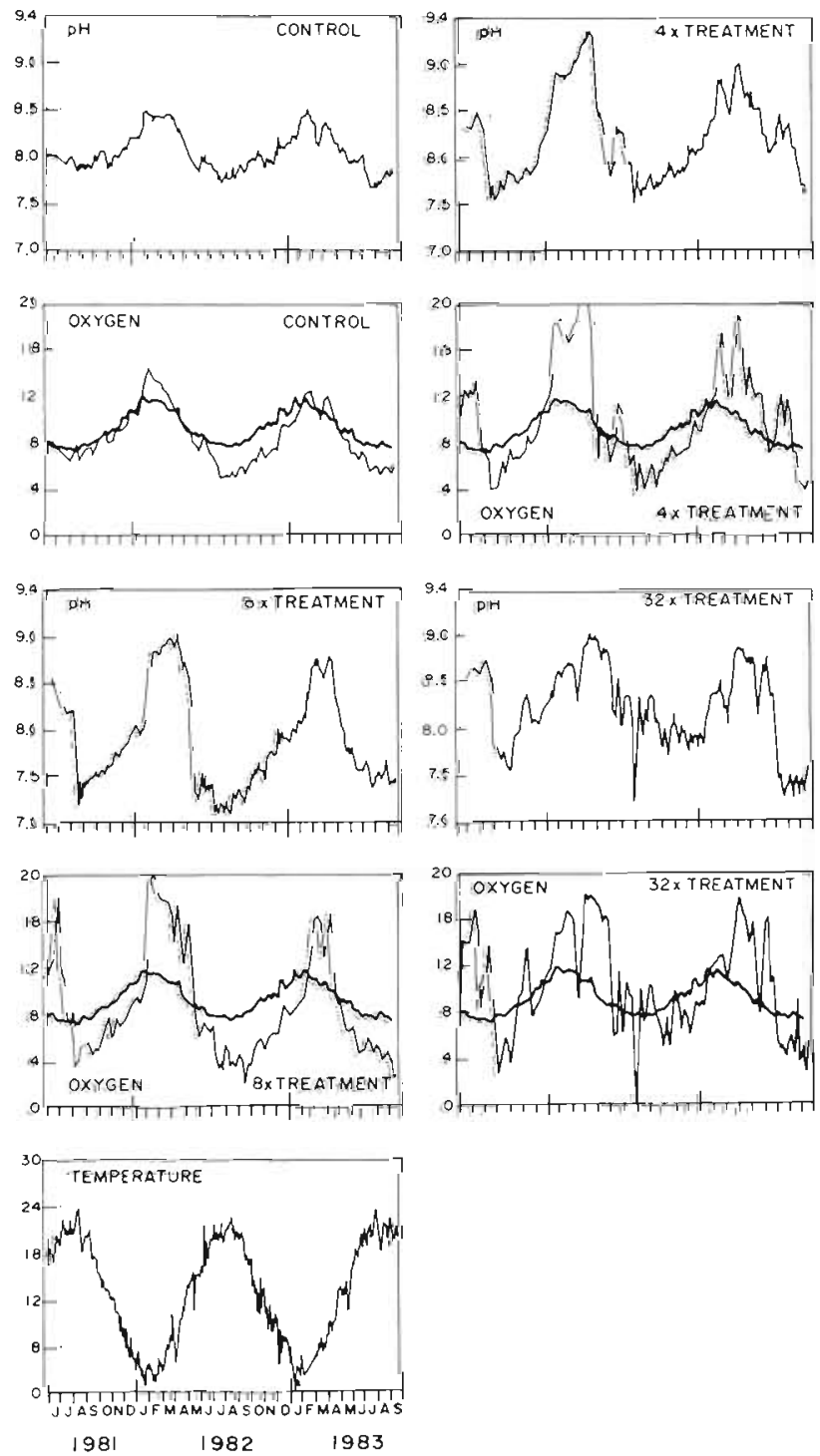

Fig. 2. Time series concentrations of $\mathrm{pH}$, oxygen $\left(\mathrm{mg} \mathrm{O}_{2} \mathrm{l}^{-1}\right)$ and temperature $\left({ }^{\circ} \mathrm{C}\right)$ for control, $4 \times, 8 \times$ and $32 \times$ treatments. Heavy lines on oxygen graphs indicate saturation concentrations 
period of anoxia was preceded and followed by autotrophic conditions in mid summer in the $32 \times$ treatment (Fig. 2). Treatment mesocosms above $4 \times$ had periods during the summer when oxygen concentrations dipped below $3.5 \mathrm{mg}^{1^{-1}}$.

Diatom dominance in the phytoplankton was marked by periods of oxygen supersaturation or autotrophy. In the first year of the experiment preserved phytoplankton cell samples of greater than $10 \mu \mathrm{m}$ in diameter were counted 38 times; in the second year, they were counted 28 times (Lane pers. comm.). These counts were roughly weekly in all treatments, although April and most of May 1983 were missed. For $95 \%$ of the time, months in which average diatom counts of weekly samples exceeded 1000 cells $\mathrm{ml}^{-1}$ were correlated with supersaturation of oxygen (Fig. 3). The $5 \%$ of the time with lack of correlation

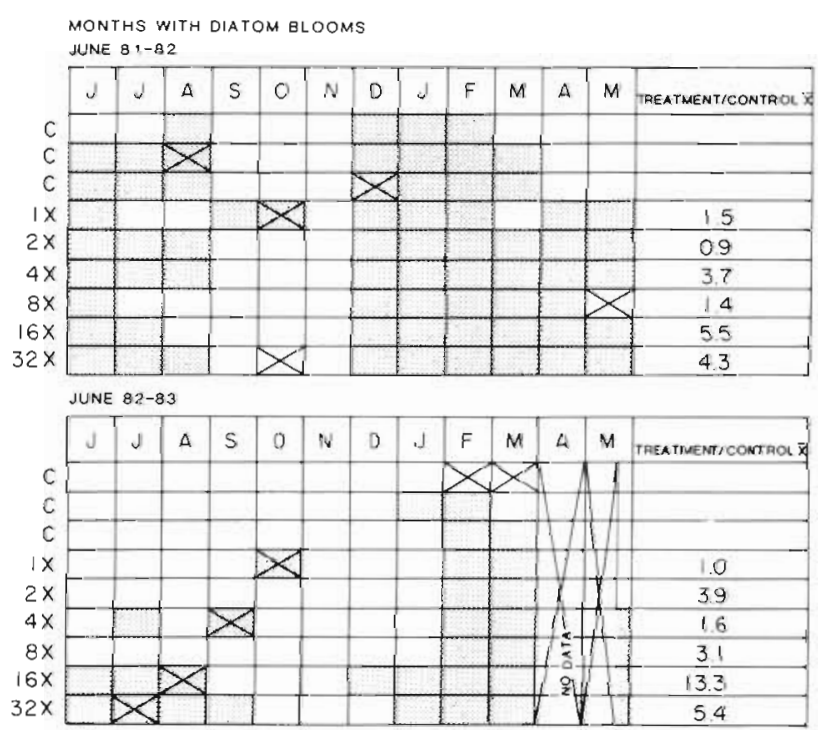

Fig. 3. Correlations between months with diatom blooms and oxygen supersaturation in the water column in all treatments for the first $2 \mathrm{yr}$ of the experiments. Months with diatoms are indicated by stippling; months without diatoms are unstippled; months without correlation or those showing lack of data are indicted by an $X$. Annual factor was calculated by dividing annual mean diatom abundance in each treatment by annual mean of the 3 controls

was probably due to the coarseness of the time scale of 1 mo, an infrequency in the count data, or a bloom of diatoms less than $10 \mu \mathrm{m}$ in size. During non-diatom or flagellate dominance, periods of heterotrophy occurred. The patterns of $\mathrm{pH}$ values correlated well with oxygen concentration levels: high values during periods of autotrophy and low values during periods of heterotrophy $(r=0.93, n=1728)$. Amplitudes and shifts in $\mathrm{pH}$ increased up the nutrient gradient (Fig 2). Above the $4 \times$ treatment, autotrophic periods measured up to 9.0 and heterotrophic periods measured down to 7.1. Temperature seasonally ranged from 0 to $24{ }^{\circ} \mathrm{C}$ in all treatments. The winter of 1983 was generally warmer and the cold period of less duration than the winter of 1982 (Fig. 2).

\section{Time series: nutrients and chlorophyll}

Periods of high chlorophyll levels had lowered nutrient levels in all treatments (Fig. 4). Highest chlorophyll levels occurred during winter-spring blooms. During these periods dissolved silica went to zero in all treatments; dissolved inorganic nitrogen went to zero in up to the $4 \times$ treatment but in higher treatments it was never limiting (Fig. 4). During summer and fall periods of low chlorophyll both silica and nitrogen reached highest concentrations.

\section{Time series: system metabolism}

Seasonal patterns of daily apparent production remained intact up the nutrient gradient with high values during the winter-spring bloom and summer, and low values during the fall (Fig. 5). Controls showed a drop in the spring of 1982 due to nutrient limitation which treatment mesocosms did not show. During the warm winter of 1983, the winter-spring
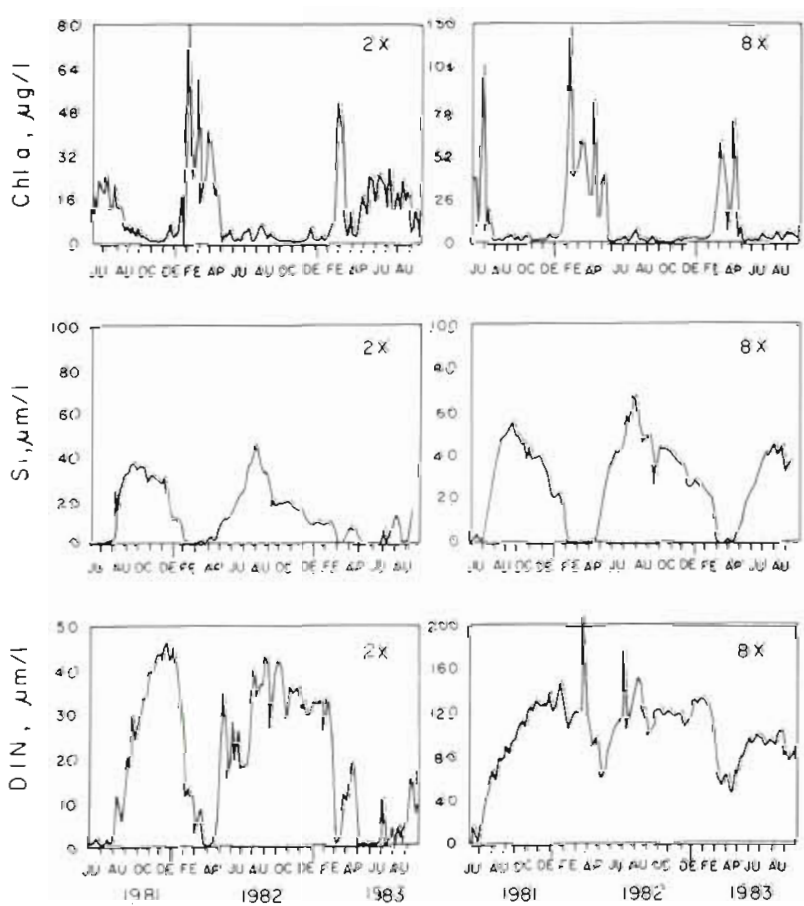

Fig. 4. Concentrations of chlorophyll, silica (Si), and dissolved inorganic nitrogen (DIN) in the $2 \times$ and $8 \times$ treatments from Jun 1981 to Sep 1983. Note changes in the $y$-axis for the 2 treatments levels 


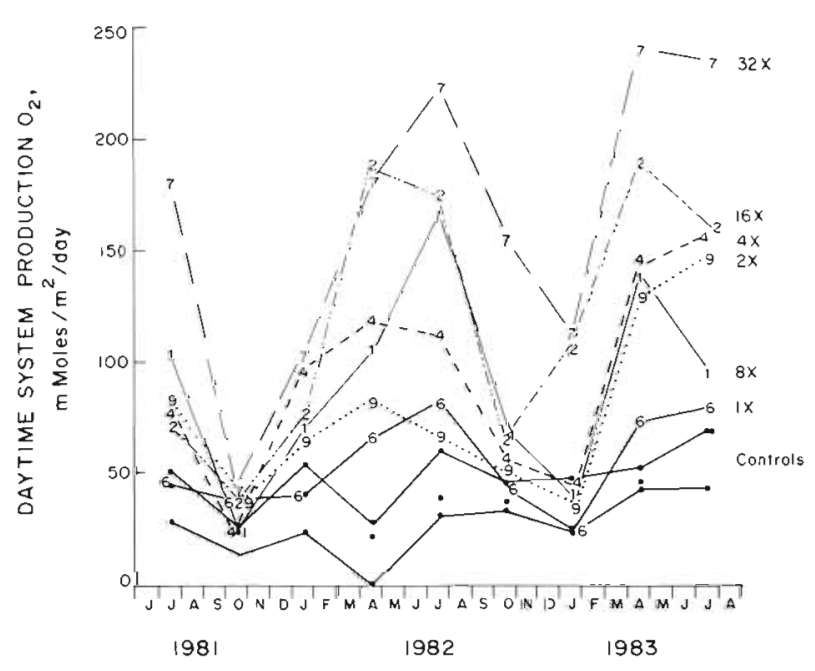

Fig. 5. System production from dawn-dusk measurements of oxygen concentration for each treatment mesocosm (numbers) and the 3 control mesocosms ( $\bullet$ ) from Jun 1981 to Aug 1983. Weekly data have been smoothed by calculating seasonal means (DJF, MAM, JJA, SON)

bloom occurred in late February and early March in all treatments. Generally, even the $1 \times$ treatment had higher values of production than the controls. However, even in $32 \times$ treatment there was only a 3.5 fold increase in system production compared to controls (Table 1).

Night respiration patterns were similar to production patterns in all treatments, but of slightly less magnitude (Fig. 6). Small year-to-year differences occurred. For example, during the warmer winter of 1983 respiration rates were higher than the winter of 1982 . Respiration rates during the summer of 1983 tended to be higher in treatment mesocosms than in summer of 1982 or 1981.

Several differences were evident in production to respiration ratios (Fig. 7 ). The first summer was more heterotrophic than were the second and third. During

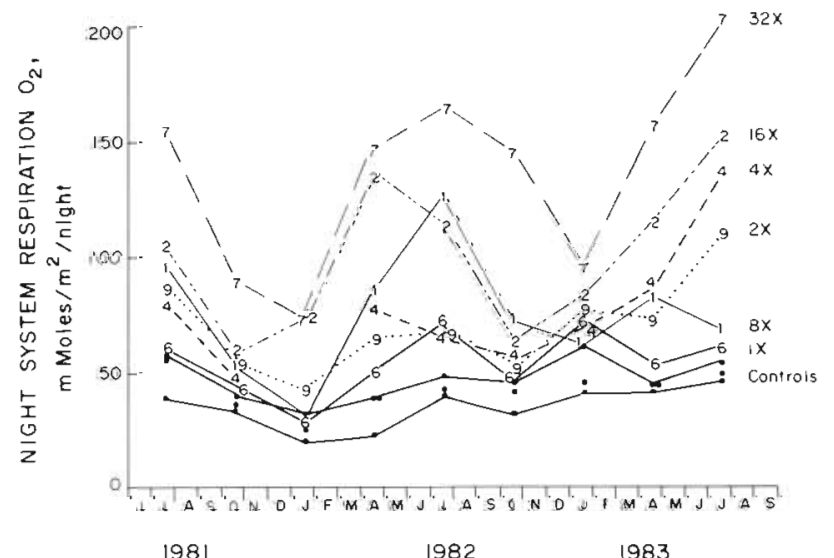

Fig. 6. System respiration from dusk-dawn measurements of oxygen concentration for each treatment mesocosm (numbers) and the 3 control mesocoms (•) from Jun 1981 to Aug 1983. Weekly data have been smoothed by calculating seasonal means (DJF, MAM, JJA, SON)

Table 1. Annual system production up the nutrient treatment gradient and water column production calculated by adding system production and daytime benthic respiration

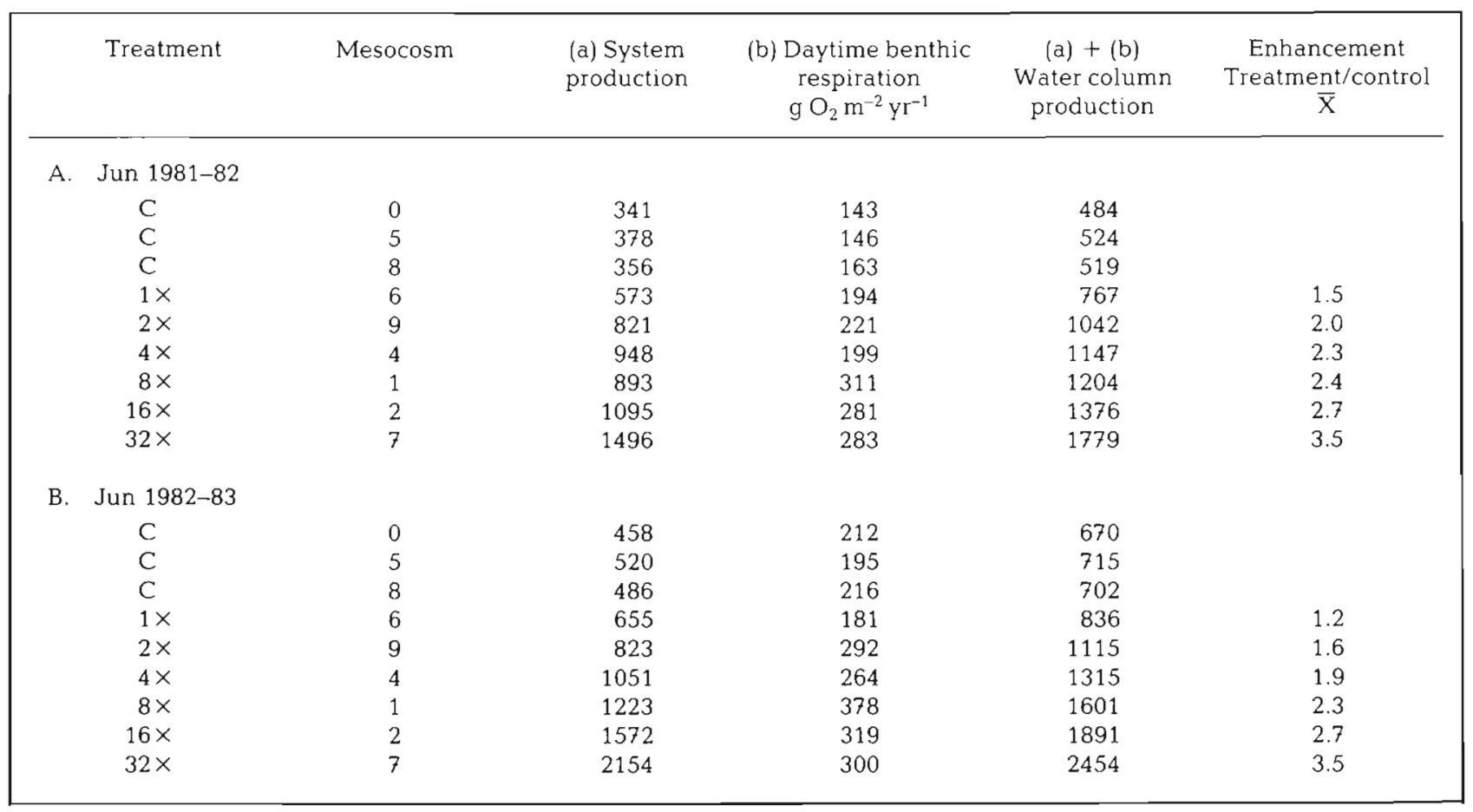


the first summer, oxygen concentrations rose in June and July but dropped sharply in August (Fig. 2). The first fall was also more heterotrophic than the second The winter-spring bloom occurred in January of the

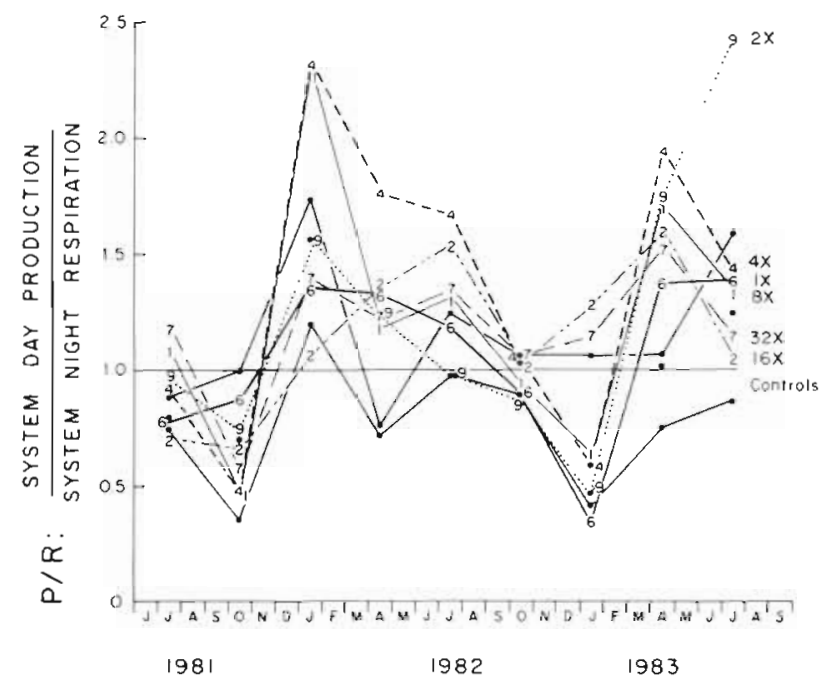

Fig. 7. System production to system respiration ratios for each treatment mesocosm (numbers) and the 3 control mesocosms (•) from Jun 1981 to Aug 1983. Weekly data has been smoothed by calculating seasonal means (DJF, MAM, JJA, SON]

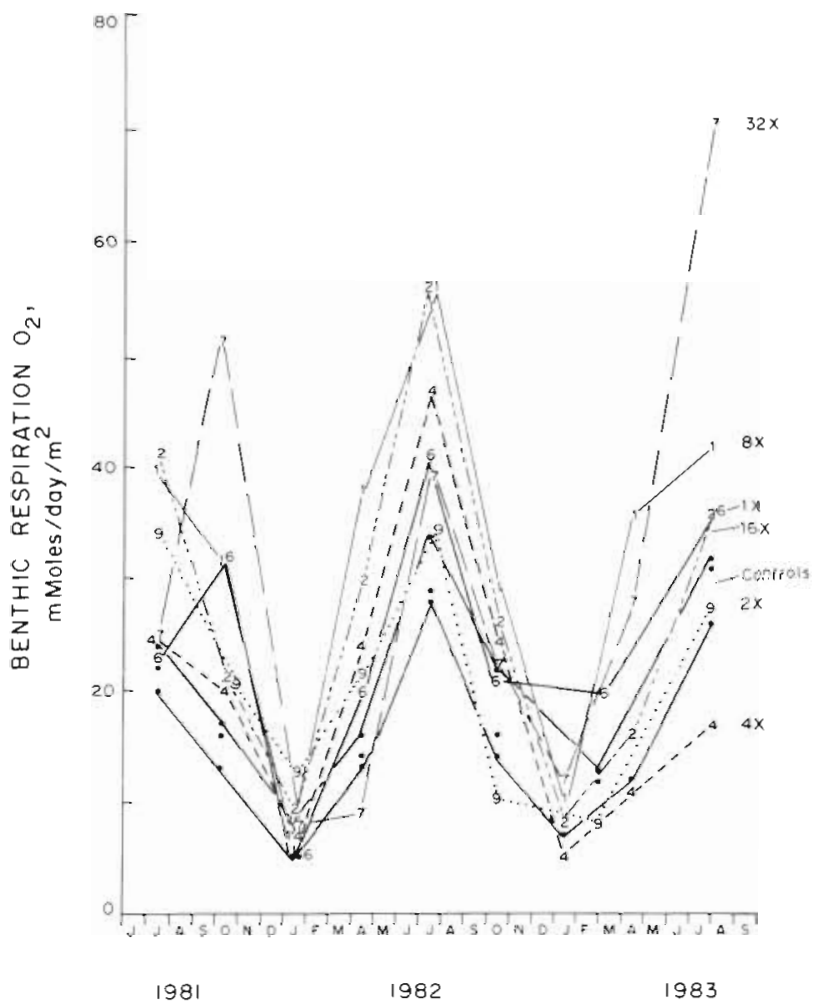

Fig. 8. Benthic respiration for each treatment mesocosm (numbers) and the 3 control mesocosms ( $)$. Data have been smoothed by calculating the seasonal means (DJF, MAM, JJA, SON) first year and during February and March of the second. Thus, most P/R ratios were low in the second year compared to the first year for the winter months. Only 2 treatments, $32 \times$ and $16 \times$ and a control, had net production during this second winter compared to maximum net productions for most treatments during the winter of the first year (Fig. 7).

\section{Benthic respiration}

Benthic respiration followed the seasonal temperature cycle strongly (Fig. 8; Nixon et al. 1976). Control and treatment mesocosms had lowest and similar values in winter. During summer, control mesocosms showed about a 2 -fold increase; the $32 \times$ treatment showed a 5 to 7 -fold increase over winter values. Treatment mesocosms, while generally higher than control mesocosms throughout summer, did not necessarily have higher values in accord with levels of nutrient addition. During the second summer, the $32 \times$ treatment fell between the $2 \times$ and $1 \times$ treatments. Low values in this treatment were correlated with low oxygen and anoxia during July and early August 1982 (Fig. 2). Since the other treatments were not consistently ordered according to nutrient addition, all values were pooled to observe correlations with temperature. For all treatments during the experiment the relation between benthic respiration (BR) and temperature $\left(\mathrm{T} ;{ }^{\circ} \mathrm{C}\right)$ was:

$$
\mathrm{BR}\left(\mathrm{mg} \mathrm{O}_{2} \mathrm{~m}^{-2} \mathrm{~h}^{-1}\right)=\mathrm{e}^{00934(\mathrm{~T})}+2.5 ; \mathrm{r}=0.67
$$

In control treatments the correlation between benthic respiration and temperature reached as high as $95 \%$; in treatments up to $32 \times$, correlations ranged from 65 to $83 \%$. Correlation in $32 \times$ was a low $37 \%$ due to the impact of low oxygen conditions during the second summer of the experiment (Fig. $2 \& 8$ ).

\section{Annual metabolism patterns}

The 32-fold nutrient enrichment resulted in a 3 to 4 fold increase in production in the first 2 yr of the experiment, but absolute magnitudes of production increased in all mesocosms during the second year (Tables 1 \& 2). In the first year controls had a system apparent production of 358 (c. $\mathrm{v} .= \pm 5 \%$ ) $\mathrm{g} \mathrm{O}_{2} \mathrm{~m}^{-2}$ $\mathrm{yr}^{-1}$ and the $32 \times$ treatment had a value of $1496 \mathrm{~g} \mathrm{O}_{2}$ $\mathrm{m}^{-2} \mathrm{yr}^{-1}$ (Table 2). During the second year controls had a mean system production of 488 (c. v. $= \pm 6 \%$ ) g $\mathrm{O}_{2} \mathrm{~m}^{-2} \mathrm{yr}^{-1}$ and the $32 \times$ treatment reached $2154 \mathrm{~g} \mathrm{O}_{2}$ $\mathrm{m}^{-2} \mathrm{yr}^{-1}$ If a P. Q. of 1.2 is assumed (Oviatt et al. 1986), these oxygen values converted to carbon become 111 , 463, 152 and $668 \mathrm{~g} \mathrm{C} \mathrm{m}^{-2} \mathrm{yr}^{-1}$ for control and $32 \times$ treatments in the first and second years, respectively. 
Table 2. Integrated system production, night respiration and system production to respiration ratios up the nutrient gradient during the first 2 yr of the experiment

\begin{tabular}{|c|c|c|c|}
\hline Treatment & $\begin{array}{l}\text { Day system } \\
\text { production }\end{array}$ & $\begin{array}{l}\text { Night system } \\
\text { respiration }\end{array}$ & $\begin{array}{l}\text { System } \\
P / R\end{array}$ \\
\hline \multicolumn{4}{|c|}{$\mathrm{gO}_{2} \mathrm{~m}^{-2} \mathrm{yr}^{-1}$} \\
\hline \multicolumn{4}{|c|}{ June 1981-82 } \\
\hline Controls & 358 (c.v. $=5 \%$ ) & 412 (c.v. $=4 \%$ ) & 0.9 \\
\hline $1 \times$ & 573 & 518 & 1.1 \\
\hline $2 x$ & 821 & 705 & 1.2 \\
\hline $4 \times$ & 948 & 891 & 1.1 \\
\hline $8 x$ & 893 & 765 & 1.2 \\
\hline $16 x$ & 1095 & 1068 & 10 \\
\hline $32 \times$ & 1496 & 1329 & 1.1 \\
\hline \multicolumn{4}{|c|}{ June $1982-83$} \\
\hline Controls & 488 (c.v. $=6 \%)$ & 542 (c. v. $=12 \%$ ) & 0.9 \\
\hline $1 \times$ & 655 & 706 & 0.9 \\
\hline $2 \times$ & 823 & 794 & 1.0 \\
\hline $4 \times$ & 1051 & 832 & 1.3 \\
\hline $8 x$ & 1223 & 1002 & 1.2 \\
\hline $16 x$ & 1572 & 1112 & 1.4 \\
\hline $32 \times$ & 2154 & 1664 & 1.3 \\
\hline \multicolumn{4}{|c|}{ Sum of the $2 \mathrm{yr}$} \\
\hline Controls & 846 & 954 & 0.90 \\
\hline $1 \times$ & 1228 & 1224 & 1.00 \\
\hline $2 \times$ & 1644 & 1499 & 1.10 \\
\hline $4 \times$ & 1999 & 1723 & 1.16 \\
\hline $8 x$ & 2116 & 1767 & 1.20 \\
\hline $16 \times$ & 2667 & 2180 & 1.22 \\
\hline $32 \times$ & 3650 & 2993 & 1.22 \\
\hline
\end{tabular}

Water column metabolism in the second year, when plotted as the natural logarithm of the treatment gradient, became linear functions:

$$
\begin{aligned}
& W C P=386 \ln N+491 ; r=0.98 \\
& W C R=173 \ln N+211 ; r=0.93
\end{aligned}
$$

where WCP and WCR = water column production and water column night respiration in $\mathrm{g} \mathrm{O}_{2} \mathrm{~m}^{-2} \mathrm{yr}^{-1}$, respectively and $\mathrm{N}$ was the daily nutrient input of nitrogen in $\mathrm{m} \mathrm{mol} \mathrm{m}^{-2} \mathrm{~d}^{-1}$ (Fig. 9).

Annual production to respiration ratios indicated a slight proportional trend of production storage up the nutrient gradient (Table 2). Control systems were heterotrophic in the first $2 \mathrm{yr}$ of the experiment with a net loss of $54 \mathrm{~g} \mathrm{O}_{2} \mathrm{~m}^{2} \mathrm{yr}^{-1}$. Treatment mesocosms, with the exception of $1 \times$ the second year, were always autotrophic. During the first year the $32 \times$ treatment showed a net accumulation of $167 \mathrm{~g} \mathrm{O}_{2} \mathrm{~m}^{-2} \mathrm{yr}^{-1}$ and during the second year, $490 \mathrm{~g} \mathrm{O}_{2} \mathrm{~m}^{-2} \mathrm{yr}^{-1}$. These accumulations indicated a net storage or export of 52 and $153 \mathrm{~g} \mathrm{C} \mathrm{m}^{-2} \mathrm{yr}^{-1}$ respectively if a $\mathrm{P}$. Q . of 1.2 is assumed (Oviatt et al. 1986). Since production and respiration generally increased in the second year of the experiment, steady state was apparently not achieved by the end of 1 yr. Thus the processes were summed over the 2 yr period and in this case a trend of increasing absolute and proportional storage/export was apparent (Table 2):

$$
\mathrm{NSP}=89 \ln \mathrm{N}-89 ; \mathrm{r}=0.99
$$

where NSP $=$ net system production in $\mathrm{g} \mathrm{O}_{2} \mathrm{~m}^{-2} \mathrm{yr}^{-1}$; $\mathrm{N}=$ the daily input of nitrogen in mmol $\mathrm{m}^{-2} \mathrm{~d}^{-1}$ (Fig. 9).

Benthic respiration for the second year when plotted as the natural logarithm of the treatment gradient was also a linear function:

$$
\mathrm{BR}=57 \ln \mathrm{N}+364 ; \mathrm{r}=0.81
$$

where $\mathrm{BR}=$ benthic respiration $(24 \mathrm{~h})$ in $\mathrm{g} \mathrm{O}_{2} \mathrm{~m}^{-2} \mathrm{~d}^{-1}$ and $\mathrm{N}=$ daily input of nitrogen in $\mathrm{mmol} \mathrm{m} \mathrm{m}^{-2} \mathrm{~d}^{-1}$ (Fig. 9). The slope of this relation (57) shows the least response to the nutrient treatment up the gradient compared to net system production (89), night water column respiration (173) and water column production (386).

With increased productivity up the nutrient gradient, the percent of water column production respired by the benthos decreased from about $55 \%$ in controls to about $25 \%$ in the $32 \times$ treatment (Fig. 10). Absolute magnitudes of benthic respiration increased up to the $8 \times$ treatment and decreased at higher levels (Table 1). The percent of daytime water column production respired on the bottom in this experiment was compared to that predicted by Hargrave (1973) for increasing productivity in a $5 \mathrm{~m}$ deep water column (the same depth as the mesocosms) (Fig. 10). The agreement with this relation was observed in the first $2 \mathrm{yr}$ of the experiment. The shift to greater productivity and benthic respiration in the second year strengthens the agreement with Hargrave's predicted relation (Fig. 10). As productivity increased up the nutrient gradient benthic metabolism decreased in relative magnitude.

\section{DISCUSSION}

\section{Comparisons to natural areas}

The relation between water column production and nutrient addition was not $1: 1$, indicating that at least for higher treatment levels nutrients were not the limiting factors (Fig. 8). In many coastal areas with lower nutrient levels, nitrogen is likely often a limiting nutrient. In a study of 14 estuaries with generally low nutrient loading, Boynton et al. (1982) found a linear correlation of $77 \%$ between annual nitrogen loading and primary production. Other factors such as extinction coefficient, flushing rates, degree of stratification and grazing pressure can be expected to cause differ- 


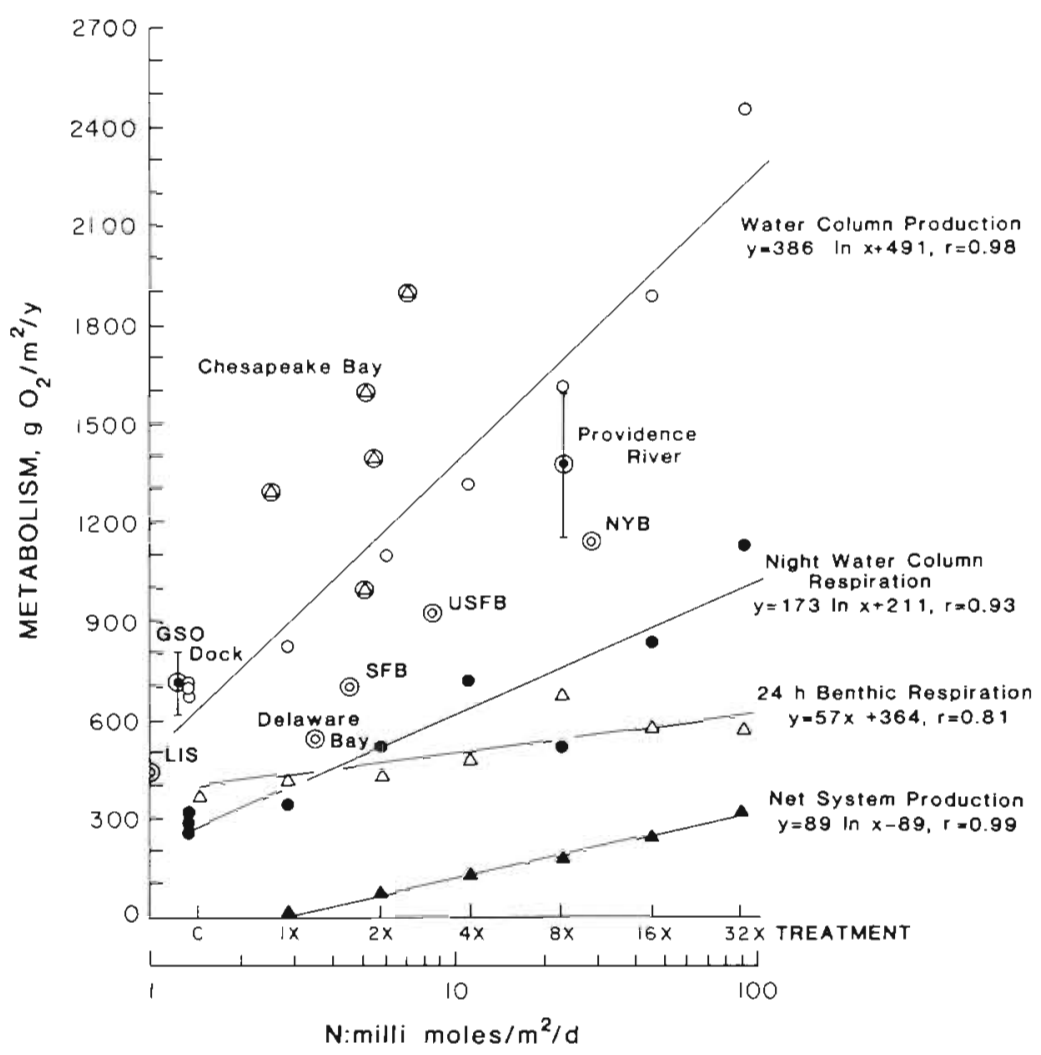

Fig. 9. Water column metabolism, production (O) and night respiration ( $\bullet$ ) plotted as a function of dissolved inorganic nitrogen input for the second year of the experiment from Jun 1982 to Jun 1983. Control mesocosms were plotted as $1 / 2$ of the $1 \times$ treatment. A few primary production values for estuarine and coastal areas are plotted for comparison: in Narragansett Bay the Graduate School of Oceanography (GSO) and the Providence River (Oviatt et al. 1981, production; Oviatt et al. 1984, N input), Chesapeake Bay, San Francisco (SFB), Long Island Sound (LIS) (Boyton et al. 1982, production and $N$ input), New York Bight (NYB) (Malone 1982, production; Mearns et al. 1982, N input). Upper San Francisco Bay (USFB) (Peterson 1979, production and $N$ input), Delaware Bay (Nixon \& Pilson 1983, production and $\mathrm{N}$ input). Benthic respiration, $24 \mathrm{~h}(\Delta)$ was plotted for the second year of the experiment Jun 1982 to Jun 1983. Net system production (ム) (System production minus system night respiration) are mean values from the first $2 \mathrm{yr}$ of the experiment (see Table 2)

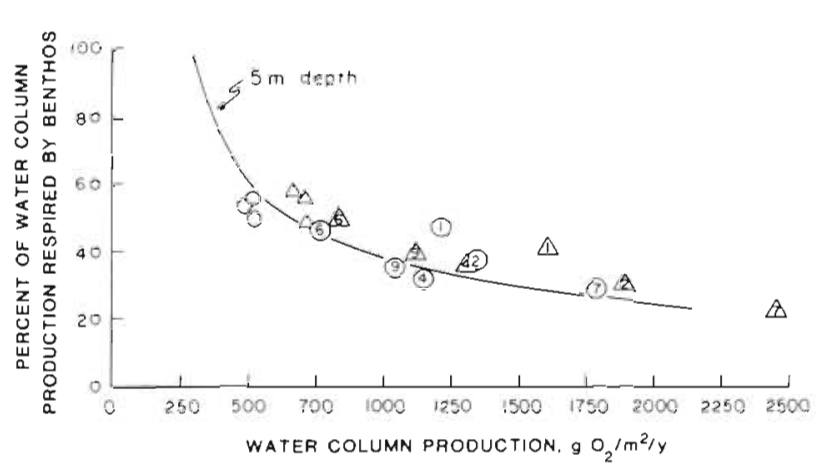

Fig. 10. Benthic respiration as percent of water column production respired by benthos versus water column production. (O) Period Jun 1981 to Jun 1982; ( $\triangle$ ) Jun 1982 to Jun 1983. Numbers refer to individual mesocosm treatments (see Table 1); unnumbered symbols are controls. The line is for a $5 \mathrm{~m}$ deep water column (from Hargrave 1973)

ences between predictions from the experimental results and natural areas. For example, both degrees of stratification and flushing rates may be causing Chesapeake Bay, with apparently low levels of nitrogen addition between the $1 \times$ and $2 \times$ levels of treatment (Fig. 9), to have large areas of anoxic bottom water during summer (Beilson \& Cronin 1981). The results from the nutrient experiment were compared to data from natural areas. In one of the few multiple year records, primary production, in Chesapeake Bay, ranged from about 1000 to $1900 \mathrm{~g} \mathrm{O}_{2} \mathrm{~m}^{-2} \mathrm{yr}^{-1}$ for an estimated nitrogen input of about 2.5 to $7.1 \mathrm{mM} \mathrm{N} \mathrm{m}^{-2}$ $\mathrm{d}^{-1}$ (Boyton et al. 1982). For all other comparisons the predicted values were higher than coastal areas (Fig. 9). Few comparisons were found for higher nutrient loadings. The 2 areas above the $8 \times$ level of treatment have or have had low oxygen problems as predicted by the experimental results (Oviatt et al. 1984, Gunnerson 1981). Despite expected variability, values for primary production in coastal areas overall compare with the experimental results.

\section{Enrichment versus system production}

Two interrelated results stand out in this experiment. First, although nutrient concentrations were enriched by a factor of 32 up the gradient, system production increased only by a factor of 3.5. This factor of productivity increase is similar to that observed in other coastal systems (Boyton et al. 1982, Nixon \& Pilson 1983). Thus an understanding of the limits to productivity in this experiment may provide new insight for field ranges of productivity. Second, periods of autotrophy and net system production were correlated with high numbers of diatoms. In the Sea of Japan, the seasonal transition from autotrophic diatoms in winterspring to a heterotrophic microplankton in summer has 
also been observed (Sorokin 1977). Thus, diatoms may be the key to understanding net system production and the amount of production available to higher trophic levels (Fig. 2, 3 \& 9).

Two factors may have limited diatom growth in this experiment: silica (Officer \& Ryther 1980), and grazing (Officer et al. 1982). During winter blooms silica always dropped to low levels in all treatments; during summer silica was abundant, but grazing pressure was high (Fig. 4).

Silica may have limited system production up the gradient in this experiment. Diatoms require a $\mathrm{N}: \mathrm{Si}$ ratio of about $2: 1$ (Harrison et al. 1977). The N: Si ratio of nutrient inputs, designed to be like sewage effluents, was $14: 1$ or off by a factor of 7 from that required for non-silica-limited diatom growth (Donaghay pers. comm.). All treatments above $1 \times$ had mean annual N:Si ratios greater than 2 . The 32 -fold factor of productivity increase reduced by a factor of 7 (from that required for non-silica-limited diatom growth) predicts about a 5 -fold factor in system diatom production up the nutrient gradient. Ratios of mean annual diatom counts in treatment and controls agree (with some exception) with this prediction (Fig. 3).

These exceptions also appear in the correlated $(\mathrm{r}=$ $0.68)$, linear relation between system net production (mean of the first $2 \mathrm{yr}$ ) and diatoms (mean of the first 2 yr) (Fig. 11). To some extent the inability of weekly counts to reflect the explosive growth and declines of phytoplankton explain non-linearities. However, grazing probably played a role. Three treatments were low compared to the linear regression: $4 \times, 8 \times$ llargest numbers and biomass of filter feeding bivalves), and $32 \times$ (largest numbers of larval polychaetes). One treatment had higher than predicted numbers of diatoms (Fig. $3 \& 11$ ): $16 \times$ (lowest numbers of benthic fauna due to highest numbers of predator shrimp). The $2 \times$ and $8 \times$ treatments were chosen to exemplify the impacts of grazing on chlorophyll and nutrient patterns (Fig. 4). In the first summer in all treatments benthic fauna was just beginning to respond to blooms stimulated by the nutrient additions. Grazing was not initially large and phytoplankton blooms were apparent. By the second summer benthic fauna were established with spionid polychaetes in $2 \times$ actively feeding on the water column (Frithsen \& Doering unpubl.) and with filter feeding bivalves in $8 \times$. Low summer chlorophyll concentrations were observed. Toward the end of the second summer the highest numbers (of all treatments) of Crangon septemspinosa shrimp appeared in $2 \times$. None appeared in $8 \times$. By the third summer all benthic fauna had been destroyed by the shrimp in the $2 \times$ treatment and chlorophyll levels increased. Filter feeders remained abundant in $8 \times$ and chlorophyll remained low in this treatment in the third summer.

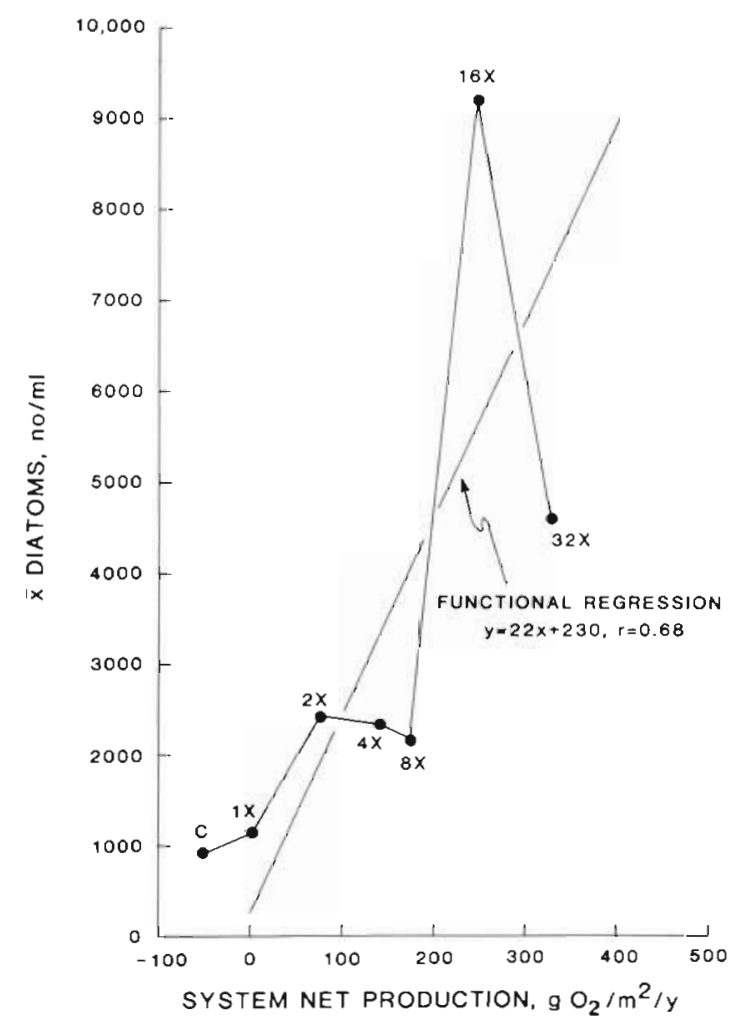

Fig. 11 Annual mean diatoms as a function of annual mean system net production for the first $2 \mathrm{yr}$ of the experiment. Functional regression line (Ricker 1973) calculated on the

basis of the mean treatment values for the 2 parameters

Nutrients during these summer periods showed inverse patterns to chlorophyll (Fig. 4). While grazing or lack of grazing appeared to affect numbers of diatoms in these treatments, no impact was observed on net system production (Fig. 9) suggesting that standing crop estimates do little to predict underlying growth rate processes of the diatoms.

\section{Benthic versus water column response}

In contrast to the metabolic response of the water column to nutrient input, the benthic metabolism exhibited a damped response with only a 1.5 -fold factor of increase in the $32 \times$ treatment compared to controls in the second year (Fig. 8). A much higher percentage of the primary productivity was respired on the bottom in controls compared to a low percentage in the upper treatment levels. This was also observed by Hargrave (1973) for field data.

The reasons for these observations may include an increased activity on the part of pelagic communities at higher primary productivity (Hargrave 1973) and a spatial limitation for respiration of organic matter at the sediment water interface and more deeply buried 
organic matter. The evidence for increased activity from the pelagic community was not apparent in the copepod community which showed little consistent response to the eutrophication gradient (Sullivan \& Ritacco 1985). A portion of the greater activity in the water column, in part, may have derived from benthic reproduction. Meroplankton from benthic polychaete reproduction were an important component of the zooplankton during summer periods (Nixon et al. 1984). There was a relatively small response of the heterotrophic microflagellates to the eutrophication gradient; other predators, such as ciliates and rotifers probably kept heterotrophic microflagellates under control (Hobbie \& Cole in press, Donaghay et al. unpubl.). Bacterial activity probably contributed in large portion to water column respiration. Numbers of bacteria and bacterial activity in the water column increased by a 5 fold factor up the nutrient gradient in the $32 \times$ treatment (Hobbie \& Cole in press). When heterotrophic microflagellates are prevented from increasing in numbers, then bacteria may be released from regulation and attain high numbers (Hobbie \& Cole in press). Overall, water column night respiration increased by a factor of 4.2 in the $32 \times$ treatment compared to controls (Fig. 9).

The evidence for spatial limitation and burial of organic matter in the sediments derives from the limited increase in benthic respiration $(24 \mathrm{~h})$ and a comparatively greater increase in the rate of net system production up the gradient (Fig. 9). Most of the net system production must have been accumulated and buried in the sediment. From the differences in chlorophyll concentrations in input water and export water we can calculate an export of 10 to $15 \%$ of net system production indicating that 85 to $90 \%$ went to the sediment. One treatment $(8 \times)$ had anomalously low respiration in the water column and anomalously high respiration in the benthos due to large numbers of small filter feeding bivalves (Fig. 9). Thus, under this circumstance, a greater activity on the part of the benthos decreased the respiratory activity in the water column. With the exception of the $8 \times$ treatment all treatments above $2 \times$ had a greater respiratory demand in the water column than the benthos (Fig. 9)

These observations suggest that the primary cause of low oxygen conditions and anoxia under eutrophic conditions was not the benthos, but enhanced heterotrophic water column activities (Fig. 2). Sorokin (1977) proposed that summer heterotrophy in the water column consumed mostly organic matter accumulated on the thermocline during the previous winter-spring bloom. Since this material goes rapidly to the bottom in the shallow, well-mixed mesocosms, and the sediment communities showed limited responses up the nutrient gradient, the winter-spring bloom was not the likely source of low oxygen conditions. Rather the lack of autotrophic activities in the water column appear to be implicated.

Acknowledgements. Dr. Scott Nixon supported and designed the eutrophication experiment; Dr. Michael Pilson provided ideas and leadership. Scott Nixon was also responsible for the benthic respiration data reported in this paper. Dr Patricia Lane of Dalhousie University was responsible for the data on diatoms. Many others on the MERL staff helped in the experiments. Steve Kelly (nutrients), Jeffrey Frithsen and David Rudnick (benthic animals) and Eric Klos (mesocosm management) particulary deserve mention. This paper benefited from discussions with Dr. Percy Donaghay who coordinated the experiment and traced out many of the interactions that occurred during the experiment. Helpful criticisms were generously given by Dr. Peter Doering and Dr. Barbara Sullivan on the MERL staff. This work was supported by EPA Cooperative Agreement 810265 and NOAA Grant 83-ABD00008 .

\section{LITERATURE CITED}

Beach, R. B. (1983). Nutrient standing stock. In: Lambert, C. E., Oviatt, C. A. (ed.) Manual of biological and geochemical techniques in coastal areas. Marine technical report 86, Univ. of Rhode Island, Kingston, 87-102

Boynton, W. R., Kemp, W. M., Keefe, C. W. (1982). A comparative analysis of nutrients and other factors influencing estuarine productivity, In: Kennedy, V S. (ed.) Estuarine comparisons. Academic Press, New York, p. 69-90

Carritt, D. E., Carpenter, J. H. (1966). Comparison and evaluation of currently employed modifications of the Winkler method for determining dissolved oxygen in sea water. J. mar. Res. 24 (3): $286-318$

Day, J. W., Jr (1983). Carbon dynamics of estuarine ponds receiving treated sewage wastes. Estuaries 6(1): 10-19

Deason, E. E. (1980). Grazing of Acartia hudsonica (A. clausi) on Skeletonema costatum in Narragansett Bay (USA): influence of food concentration and temperature. Mar Biol. 60: 101-113

Deason, E. E., Smayda, T. J. (1982). Ctenophore-zooplanktonphytoplankton interactions in Narraganett Bay, Rhode Island, USA during 1972-77 J. Plankton Res. 4(2): 203-217

Durbin, A. G., Durbin, E. G. (1981). Standing stock and estimated production rates of phytoplankton and zooplankton in Narragansett Bay, Rhode Island. Estuaries 4: $24-41$

Durbin, E. G., Krawiec, R. W., T. J. Smayda. (1975). Seasonal studies on the relative importance of different size fractions of phytoplankton in Narragansett Bay (USA). Mar Biol. 32: 271-287

Furnas, M. J. (1928). The dynamics of summer phytoplankton populations in Narragansett Bay. Ph. D. thesis, Univ. of Rhode Island, Kingston

Furnas, M. J., Hitchcock, G. L., Smayda, T. J. (1982). Nutrientphytoplankton relationships in Narragansett Bay during the 1974 summer bloom. In: Wiley, M. (ed.) Estuarine processes, Vol. 1. Uses, stresses and adaptation to the estuary. Academic Press, New York, p. 118-134

Gunnerson, C. G. (1981). The New York Bight ecosystem. In: Geyer, R. A. (ed.) Marine environmental pollution, 2, Dumping and mining Elsevier Scientific Publ. Co., New York, p. 313-378 
Hargrave, B. T (1973). Coupling carbon flow through some pelagic and benthic communjties. J. Fish. Res. Bd Can. 30 $1317-1326$

Harrison, P. J., Conway, H. L., Holmes, R. W., Davis, C. O. (1977). Marine diatoms grown in chemostats under silicate or ammonium limitation III. Cellular chemical composition and morphology of Chaetoceros debilis, Skeletonema costatum and Thalassiosira gravida. Mar Biol. 43: 19-31

Hobbie, J. E., Cole, J. J. (1984). Response of a detrital food web to eutrophication. Bull. mar Sci. 35 (3): 357-363

Lorenzen, C. J. (1966). A method for the continuous measurement of in vivo chlorophyll concentration. Deep Sea Res 13: $223-227$

Malone, T. C. (1982). Factors influencing the fate of sewage derived nutrients in the lower Hudson Estuary and New York Bight. In: Mayer, G. F. (ed.) Ecological stress and the New York Bight: science and management. Estuarine Research Federation, Columbia, South Carolina, p. $389-400$

Margalef, R. (1958). Temporal succession and spatial heterogeneity in phytoplankton. In: Buzzati-Traverso, A. A. (ed.) Perspectives in marine biology. Univ. California Press, Berkeley, p. 323-349

McLaughlin, J. J. A., Kleppel, G. S., Brown, M. P., Ingram, R. J., Samuels, M. B. (1982). The importance of nutrients to phytoplankton production in New York Harbor. In: Mayer, G. F. (ed.) Ecological stress and the New York Bight: science and management. Estuarine Research Federation, Columbia, South Carolina, p. 469-479

Martin, J. H. (1965). Phytoplankton-zooplankton relationships in Narragansett Bay. Limnol. Oceanogr. 10: 185-191

Mearns, A. J., Haines, E., Kleppel, G. S., McGrath, R. A., Mc Laughlin, J. S. A., Segar, D. A., Sharp, J. H., Walsh, S. S., Word, J. Q., Young, D. K., Young, M. M. (1982). Effects of nutrients and carbon loadings on communities and ecosystems. In: Mayer, G. F. (ed.) Ecological stress and the New York Bight: science and management. Estuarine Research Federation, Columbia, South Carolina, p. 53-66

Neilson, B. J., Cronin, L. E. (ed.) (1981). Estuaries and nutrients. Humana press, Clifton, New Jersey

Nixon, S. W (1984). Nutrient dynamics and the productivity of marine coastal waters. In: Halwagy, R. (ed.) First Arabian Gulf conference on environment and pollution, Kuwait, 7-9 February 1982. Alden Press, Oxford, p. $97-115$

Nixon, S. W., Pilson, M. E. Q. (1983). Nitrogen in estuarine and coastal marine ecosystems. In: Carpenter, E. J., Capone, D. G. (ed.) Nitrogen in the marine environment. Academic Press, New York, p. 565-648

Nixon, S. W., Oviatt, C. A., Hale, S. S. (1976). Nitrogen regeneration and the metabolism of coastal marine bottom communities. In: Anderson, J. M., Macfadyen, A. (ed.) The role of terrestrial and aquatic organisms in decomposition processes. Blackwell, Oxford, p. 269--283

Nixon, S. W., Alonso, D., Pilson, M. E. Q., Buckley, B. A. (1980). Turbulent mixing in aquatic microcosms. In: Giesy, J. P. (ed.) Microcosms in ecological research. DOE Symposium series, Augusta, Georgia, Nov. 8-19, 1978. CONFERENCE 781101, National Technical Information Service (NTIS), p. 818-849

Nixon, S. W., Pilson, M. E. Q., Oviatt, C. A., Donaghay, P., Sullivan, B., Seitzinger, S., Rudnick, D., Frithsen, J. (1984). Eutrophication of a coastal marine ecosystem - an experimental study using MERL microcosms. In: Fasham, M. J. R. (ed.) Flows of energy and materials in marine ecosystems: theory and practice. Plenum Press, New York, p. $105-135$
Odum, H. T., Hoskin, C. M. (1958). Comparative studies on the metabolism of marine waters. Publs Inst. mar Sci Univ. Tex. 5: 16-46

Officer, C. B., Smayda, T. J., Mann, R. (1982). Benthic filter feeding: a natural eutrophication control. Mar Ecol. Prog. Ser 9: 203-210

Officer, C. B., Ryther, S. H. (1980). The possible importance of silicon in marine eutrophication. Mar Ecol. Prog. Ser. 3: 83-91

Oviatt, C. A., Buckley, B., Nixon, S. (1981). Annual phytoplankton metabolism in Narragansett Bay calculated from survey field measurements and microcosm observations Estuaries 4 (3): 167-175

Oviatt, C. A., Pilson, M. E. Q., Nixon, S. W., Frithsen, J. B. Rudnick, D. T., Kelly, J. R., Grassle, J. F., Grassle, J. P. (1984). Recovery of a polluted estuarine system: a mesocosm experiment. Mar Ecol. Prog. Ser 16: 203-217

Oviatt, C. A., Rudnick, D., Keller, A., Sampou, P., Almquist, G. (1986). A comparison of system $\left(\mathrm{O}_{2}\right.$ and $\left.\mathrm{CO}_{2}\right)$ and $\mathrm{C}-14$ measurements of metabolism in estuarine mesocosms. Mar Ecol. Prog. Ser 28: 57-67

Peterson, D. H. (1979). Sources and sinks of biologically reactive oxygen, carbon, nitrogen, and silica in northern San Francisco Bay: the urbanized estuary. Allen Press, Lawrence, Kansas

Pilson, M. E. Q. (1985). On the residence time of water in Narragansett Bay. Estuaries 8 (1): 2-14

Pilson, M. E. Q., Oviatt, C. A., Vargo, G. A., Vargo, S. L. (1979). Replicability of MERL microcosms: initial observations. In: Jacoff, F. S. (ed.) Advances in marine environmental research. Proc of a Symposium, June 1977, EPA600/9-79-035. ERL-N, Narragansett, Rhode Island, p. $359-381$

Platt, T., Subba Rao, D. V (1973). Primary production of marine microphytes. In: Cooper, J. (ed.) Photosynthesis and productivity in different environments. International Biological Programm 3, Cambridge University Press, New York, p. 249-280

Pratt, D. M. (1965). The winter-spring diatom flowering in Narragansett Bay. Limnol. Oceanogr 10: 173-184

Ricker, W E. (1973). Linear regressions in fishery research. J. Fish. Res. Bd Can. 30: 409-434

Roques, P. (1985). Rate and stoichiometry of nutrient regeneration in an anoxic estuary. Ph. D. thesis, Univ. Rhode Island, Kingston

Smayda, T J. (1976). Plankton processes in mid-Atlantic nearshore and shelf waters and energy related activities. In: Manowitz, B. (ed.) Effects of energy related activities on the Atlantic continental shelf. Proc of a conference at Brookhaven National Laboratory, Nov. 10-12, 1975. BNL 50484, Upton, Long Island, p. 70-94

Smetacek, V., von Bodungen, B., Knoppers, B., Peinert, R., Pollehne, F., Stegmann, P., Zeitzschel, B. (1984). Seasonal stages characterizing the annual cycle of an inshore pelagic system. Rapp. P. v. Réun. Cons. int. Explor Mer 183: $126-135$

Sorokin, Y. J. (1977). The heterotrophic phase of plankton succession in the Japan Sea. Mar. Biol. 41: 107-117

Sullivan, B. K., Ritacco, P. J. (1985). Ammonia toxicity to larval copepods in eutrophic marine ecosystems: a comparison of results from bioassays and enclosed experimental ecosystems. Aquat. Toxicol. 7: in press

Williams, K. (1984). An overview of secondary production in pelagic ecosystems. In: Fasham, M. J. R. (ed.) Flows of energy and materials in marine ecosystems: theory and practice. Plenum Press, New York, p. 361-406

Williams, P. J. B. (1984). Bacterial production in the marine 
food chain: the emperor's new suit of clothes. In: Fasham, M. J. R. (ed.) Flows of energy and materials in marine ecosystems: theory and practice. Plenum Press, New York, p. 271-300
Yentsch, C. S., Menzel, D. W. (1963). A method for the determination of phytoplankton chlorophyll and phaeophytin by fluorescence. Deep Sea Res. 10: 221

This paper was submitted to the editor; it was accepted for printing on September 23, 1985 